\title{
Research on Distributed Power Planning Based on Supply Equipment Capacity Limitation
}

\author{
Qiulin Liu ${ }^{1}$ Xiaofan $\mathrm{Xie}^{1}$ Lei Wang $^{2 *}$ \\ ${ }^{1}$ Ganzhou Branch of State Grid Jiangxi Electric Power Company \\ ${ }^{2}$ Shanghai University of Electric Power
}

\begin{abstract}
Due to the rapid economic development in recent years, the original transformers and other power supply equipment is difficult to meet the demand of the rapid growth of electricity consumption. In order to reduce the cost of power supply, adding photovoltaic/wind power/energy storage system is an effective means to meet the demand of users to achieve regional balance without the overall reform of the system. In this paper, with reference to Ganzhou region under different growth rate of electricity a internal power supply area, considering the three-phase imbalance and photovoltaic (pv) power supply under different weather factors efficiency under different conditions, building composed of piconets and time division at micro network life period earnings are applied to solve the highest net present value as the goal on the premise of micro power grid planning for the next step, meet the increasing social demand of power supply area, improve power supply reliability, provide strong theoretical support. Finally, based on the power supply load of a certain region in Ganzhou, the method is calculated and proved to be effective.
\end{abstract}

\section{INTRODUCTION}

Traditional power grid planning usually takes a larger region as the research object and meets the needs of economic development through overall planning. With the rapid growth of power supply load, distributed power is widely used. In recent years, the traditional centralized management of active distribution network has been developed into the decentralized management of coordinated operation of micro-grid group, which can meet the regional balance of load, reduce line loss, reduce the cost of grid infrastructure and meet the increasing demand of electricity in society.

At present, a larger number of researches have been carried out in China in the aspect of microgrid planning, but the shortcomings are mainly shown in [1][2][3][4]:

(1) How to improve system stability when distributed power is integrated into large grid;

(2) How to improve the power quality and reliability of the system through control strategy optimization when part of the distributed power supply is uncontrollable, especially when a large number of rectifier devices are used;

(3) How to reduce the overall investment of power supply enterprises and the impact of existing system transmission capacity constraints on distributed power planning;

The establishment of microgrid planning model focuses on two aspects, namely, objective function and constraint conditions. It focuses on achieving maximum benefits under the condition of regional balance. The general objective function includes the following [5][6][7][8]:

(1) Raise revenue targets for power supply enterprises: The objective function is based on the economic operation of the microgrid mainly from the perspective of economic benefits of power supply enterprises. The influencing factors include the construction, operation and maintenance costs of distributed power supply and energy storage equipment to reduce the comprehensive cost of the system side:

(2) Objectives for comprehensive social and environmental benefits: Reducing environmental costs while focusing on economy is also considered. Some distributed power generating electricity, so it is necessary to take into account the cost of environmental pollution control while improving economy.

(3) Power supply reliability target: It is necessary to provide qualified high-quality electric energy, avoid the defects such as too low voltage and insufficient reactive power under heavy load, and ensure the safe and reliable operation of the system.

Ganzhou is located in the subtropical monsoon climate zone, the terrain is given priority to with mountains, hills, basins, large population, weak industrial base, in the rare earth mining as the main pillar, user load increases rapidly in recent years, this paper USES the Ganzhou power supply range, a region building composed of piconets and time division to micro network life period returns the net present value of the highest power grid planning for target under the premise, the main characteristic lies in: 1, on the premise of not transmission network comprehensive renovation, by increasing the pv/wind/energy storage 
system to meet user's demand and reduce the construction cost of power supply enterprise; 2. Considering the influence of different weather on photovoltaic power generation, planning and configuration of photovoltaic, wind power and energy storage micro grid; 3 . Consider the greatest impact of time-of-use electricity price on the revenue of micro-grid. Finally, based on the data of power supply load in a region of Ganzhou, the method is calculated to prove its effectiveness.

\section{MATERIAL AND METHODS [9][10][11][12]}

The user load at time $\mathrm{t}$ of seasonal $s_{i}$ in a power supply area is $L_{s_{i}}(t)$, Assuming that the annual load increases with a fixed growth rate of $L_{s_{i}}(t)$, and the social planning period is $T$ years, the user load at the end of the planning period is

$$
(1+r T) L_{s_{i}}(t)
$$

Under the time-of-use electricity price, the user's load will change according to the adjustment of electricity price, and there are multiple models to predict the user's load under different time-of-use electricity price schemes. Here, the elastic matrix is used to describe the response of electricity price on the user's demand side. Assume that the electricity consumption of seasonal $s_{i}$ in the peak flat and valley periods in this region is $L_{s_{i}, p}, L_{s_{i}, f}, L_{s_{i}, v}$ respectively, The elastic relationship between electricity quantity and price is defined as $e=\frac{\Delta L / L_{0}}{\Delta p / p_{0}}, L_{0}$ and $p_{0}$ represent the initial user load and electricity price, while $\Delta L$ and $\Delta p$ represent the load and electricity price changes.

Assume that the electricity consumption in each period before the implementation of time-of-use electricity price in season $s_{i}$ is $L_{s_{i}}^{(0)}=\left[L_{s_{i}, p}^{(0)}, L_{s_{i}, r}^{(0)}, L_{s_{i}, v}^{(0)}\right]^{T}$, and the electricity consumption in each period after the implementation of time-of-use electricity price is denoted as $L_{s_{i}}=\left[L_{s_{i}, p}, L_{s_{i}, r}, L_{s_{i}, v}\right]^{T}$, then

$$
L_{s_{i}}=L_{s_{i}}^{(0)}+\left[\begin{array}{ccc}
L_{s_{i}, p}^{(0)} & 0 & 0 \\
0 & L_{s_{i}, r}^{(0)} & 0 \\
0 & 0 & L_{s_{i}, v}^{(0)}
\end{array}\right]\left[\begin{array}{lll}
e_{p p} & e_{p r} & e_{p v} \\
e_{r p} & e_{r r} & e_{r v} \\
e_{v p} & e_{v r} & e_{v v}
\end{array}\right]\left[\begin{array}{c}
\Delta p_{p} / p_{p, 0} \\
\Delta p_{r} / p_{r, 0} \\
\Delta p_{v} / p_{v, 0}
\end{array}\right]
$$

Where $E=\left[\begin{array}{lll}e_{p p} & e_{p r} & e_{p v} \\ e_{r p} & e_{r r} & e_{r v} \\ e_{v p} & e_{v r} & e_{v v}\end{array}\right]$ is the elasticity matrix of electricity quantity and price in three periods, for example, $e_{p p}, e_{r r}, e_{v v}$ are self-elastic coefficients, with a value of negative, representing the relative growth amount of electricity consumption brought by the increase value of unit relative electricity price in each period of time, and $e_{p v}$ represents the relative growth amount of electricity consumption in peak period brought by the relative growth value of unit relative electricity price in valley period. $\Delta p_{p}, \Delta p_{r}, \Delta p_{v}$ are the amount of change based on the initial electricity price $p_{p, 0}, p_{r, 0}, p_{v, 0}$ in three periods of peak regular and valley. In this way, the user load corresponding to the time-of-use electricity price considering demand growth can be predicted according to Equations (1)-(2).

Under the condition of limited power supply capacity in a power supply area in, in order to cope with the rapid growth of new power demand of power users in this region, it is necessary to plan and construct wind-photovoltaicstorage microgrid, and consider the influence of time-ofuse electricity price on load balance of power users. The decision variables of this optimization problem are the

$$
C_{W}=N_{W}\left(c_{W, 0}+c_{W, 1} \sum_{k=1}^{n_{W}} \frac{1}{\left(1+r_{0}\right)^{k T} W}+c_{W, 2} \sum_{k=1}^{T} \frac{1}{\left(1+r_{0}\right)^{k}}-\frac{1}{\left(1+r_{0}\right)^{T}} \frac{n_{W} T_{W}-T}{T_{W}} c_{W, 1}\right),
$$

The last item represents the residual net present value of a single fan in the fan system at the end of the planning period.

Similarly, the net present value of photovoltaic cost is set as $C_{D G}$, the net present value of energy storage system cost is set as $C_{B}$, the life of light and storage system is recorded as $T_{D G}, T_{B}$, the replacement times in the planning number of fans, photovoltaic and energy storage, denoted as $N_{W}, N_{B}, N_{P V}$ respectively, and the time-of use electricity price of microgrid which is denoted as $p_{\text {micro }}(t)$,. Time-of-use electricity price includes four types: high peak, peak, regular and valley, denoted as $p_{\text {micro }, p,} p_{\text {micro, } p}, p_{\text {micro, },}, p_{\text {micro, } v}$.

Taking the total income of microgrid planning as the objective function, the enterprise maximizes its economic benefit by studying the total investment cost and the total income during the operation period respectively [13] [14].

Set the net present value of micro grid investment cost as $C_{\text {Total }}$, and study the net present value of windphotovoltaic-storage system respectively. Take the net present value of the cost of the fan system as $C_{W}$, let the life of the fan system be $T_{W}$, the number of fan replacement times in the planning period be $n_{W}$, the installation unit price of the fan is $c_{W, 0}$ yuan/unit, the replacement unit price of the fan is $c_{W, 1}$ yuan/unit, and the annual operation and maintenance cost of the fan is $c_{W, 2}$ yuan/year/unit, which can generally be taken as a proportion of the installation cost. In this paper, $c_{W, 2}=$ $0.5 \% c_{W, 0}$. Then the net present value of the fan system cost is

period are respectively $n_{D G}, n_{B}$, the installation unit price of the two types of systems are $c_{D G, 0}, c_{B, 0}$ yuan/unit, the replacement unit prices are $c_{D G, 1}, c_{B, 1}$ yuan/unit, and the annual operation and maintenance costs are $c_{D G, 2}, c_{B, 2}$ yuan/year/unit. Then, the net present value of the cost of photovoltaic system and energy storage system are 


$$
\begin{gathered}
C_{D G}=N_{D G}\left(c_{D G, 0}+c_{D G, 1} \sum_{k=1}^{n_{D G}} \frac{1}{\left(1+r_{0}\right)^{k T_{D G}}}+c_{D G, 2} \sum_{k=1}^{T} \frac{1}{\left(1+r_{0}\right)^{k}}-\frac{1}{\left(1+r_{0}\right)^{T}} \frac{n_{D G} T_{D G}-T}{T_{D G}} c_{D G, 1}\right), \\
C_{B}=N_{B}\left(c_{B, 0}+c_{B, 1} \sum_{k=1}^{n_{B}} \frac{1}{\left(1+r_{0}\right)^{k T_{B}}}+c_{B, 2} \sum_{k=1}^{T} \frac{1}{\left(1+r_{0}\right)^{k}}-\frac{1}{\left(1+r_{0}\right)^{T}} \frac{n_{B} T_{B}-T}{T_{B}} c_{B, 1}\right), \\
C_{G}=N_{G}\left(c_{G, 0}+c_{G, 1} \sum_{k=1}^{n_{G}} \frac{1}{\left(1+r_{0}\right)^{k T_{G}}}+c_{G, 2} \sum_{k=1}^{T} \frac{1}{\left(1+r_{0}\right)^{k}}-\frac{1}{\left(1+r_{0}\right)^{T}} \frac{n_{G} T_{G}-T}{T_{G}} c_{G, 1}\right) .
\end{gathered}
$$

To sum up, the total cost is

$$
C_{\text {Total }}=C_{W}+C_{D G}+C_{B}+C_{G} .
$$

Operating period total net present value calculation, a microgrid electricity price for $p_{\text {micro }}(t)$, when microgrid output can not meet the demand of electric power, from the main power purchase, microgrid from main power purchase price is set to $p_{\text {macro }}(t)$, microgrid can't given there was an abandoned electric power resources, have

$$
\begin{gathered}
E_{\text {total }}=\sum_{k=1}^{T} \sum_{i=1}^{4} \frac{1}{4} \times 365 \times \frac{1}{\left(1+r_{0}\right)^{k}} \times \\
\int_{0}^{24}\left[p_{\text {micro }}(t) L_{s_{i}}(t)-p_{\text {aband }}(t) L_{s_{i}, \text { aband }}(t)-p_{\text {macro }}(t) L_{s_{i}, \text { macro }}(t)\right] d t
\end{gathered}
$$

Discrete 24 hours in a day and divide them into $n$ equal parts. Take $\Delta t=\frac{24}{n}$ and the discrete moment is $t_{k}=$

$$
\begin{gathered}
E_{\text {total }}=\sum_{k=1}^{T} \sum_{i=1}^{4} \frac{1}{4} \times 365 \times \frac{1}{\left(1+r_{0}\right)^{k}} \times \\
\sum_{k=1}^{n}\left[p_{\text {micro }}\left(t_{k}\right) L_{s_{i}}\left(t_{k}\right)-p_{\text {aband }}\left(t_{k}\right) L_{s_{i}, \text { aband }}\left(t_{k}\right)-p_{\text {macro }}\left(t_{k}\right) L_{s_{i} \text { macro }}\left(t_{k}\right)\right] \Delta t .
\end{gathered}
$$

According to Equations (4) and (6), the total revenue in the planning period of microgrid can be obtained. Therefore, the objective function of this optimization problem is

$$
\begin{aligned}
& \max F=E_{\text {total }}-C_{\text {total }} . \\
& \left\{\begin{array}{l}
Q_{s_{i}, B}\left(t_{k+1}\right)=Q_{s_{i, B}}\left(t_{k}\right)+\mu_{s_{i,} \text { Charge }} \\
P_{s_{i, \text { Charge }}}\left(t_{k}\right)+P_{s_{i, \text { Discharge }}}\left(t_{k}\right)=0, \\
0 \leq P_{s_{i, \text { Charge }}}\left(t_{k}\right) \leq P_{s_{i, \text { Charge }}}^{\text {max }} \\
0 \leq P_{s_{i, \text { Discharge }}}\left(t_{k}\right) \leq P_{s_{i, \text { Discharge }}}^{\text {max }} \\
Q_{s_{i}, B}^{\min _{B_{B}}} \leq Q_{s_{i}, B} \leq Q_{s_{i, B}}^{\max _{B_{B}}}
\end{array}\right.
\end{aligned}
$$

The constraints of the above optimization problem are discussed below:

(1) Energy storage system constraints

Let the energy storage at the time $t_{k}$ of a day in $s_{i}$ season be
Where, $Q_{s_{i} B}\left(t_{k}\right)$ is the energy storage capacity at $t_{k}$ in a day of seasonal $s_{i}$ in a day, and the rated capacity of the energy storage system is $N_{B} q_{B}$, where $N_{B}$ is the number of energy storage elements, and $q_{B}$ is the rated capacity of each energy storage element. $P_{s_{i} \text {, Charge }}\left(t_{k}\right)$ $P_{s_{i} \text { Discharge }}\left(t_{k}\right)$ respectively represent charging power and discharging power, $\mu_{s_{i} \text { Charge }}$ and $\mu_{s_{i, \text { Discharge }}}$ respectively represent charging efficiency and discharging efficiency, $P_{S_{i} \text {, Charge }}^{\max }$ and $P_{s_{i} \text { Discharge }}^{\max }$ respectively represent the upper limit of charging power and discharging power, $Q_{S_{i}, B}^{\min }$ and $Q_{s_{i}, B}^{\max }$ respectively represent the lower limit and upper limit of the state of charge stored energy. Generally, $Q_{s_{i}, B}^{\min _{B_{B}}}, Q_{s_{i, B}}^{\max _{B_{B}}}$ are advisable.

(2) Energy balance constraints [15] 
When the distributed power generation $L_{s_{i}, D G}(t)$ and energy storage provided by the microgrid are less than the user's power load $L_{s_{i}}(t)$, the microgrid needs to purchase power from the main grid, i.e.

$$
L_{s_{i}, \text { macro }}(t)=L_{s_{i}}(t)-\left(L_{s_{i}, D G}(t)+P_{s_{i} \text {, Discharge }}(t)-P_{s_{i, \text { Charge }}}(t)\right) .
$$

Conversely, when the distributed generation $L_{s_{i}, D G}(t)$ and energy storage provided by the microgrid are greater than the user's power load $L_{s_{i}}(t)$, i.e. $L_{s_{i}, D G}(t)+$

$$
L_{s_{i}, \text { aband }}(t)=\left(L_{s_{i}, D G}(t)+P_{s_{i, \text { Discharge }}}(t)-P_{s_{i, \text { Charge }}}(t)\right)-L_{s_{i}}(t) .
$$

If considering the increase of user load, the electricity purchased from the main network here should be updated to

$$
L_{s_{i}, \text { macro }}(t)=(1+r T) L_{s_{i}}(t)-\left(L_{s_{i}, D G}(t)+P_{s_{i \text {, Discharge }}}(t)-P_{s_{i, \text { Charge }}}(t)\right) .
$$

(3) Demand response constraints

The total electricity purchase cost of seasonal $\mathrm{Si}$ before and after time-of use electricity price is considered,

$$
\left\{\begin{array}{l}
C_{s_{i}}^{(0)}=\int_{0}^{24} p_{0} L_{s_{i}}(t) d t \\
C_{s_{i}}^{(1)}=\int_{t \in I_{\text {peak }}} p_{\text {micro }, p} L_{s_{i}}(t) d t+\int_{\text {teI }_{\text {regular }}} p_{\text {micro }, r} L_{s_{i}}(t) d t+\int_{t \in I_{\text {valley }}} p_{\text {micro }, v} L_{s_{i}}(t) d t
\end{array}\right.
$$

Among them, $I_{\text {peak }}, I_{\text {regular }}, I_{\text {valley }}$ respectively represent the time interval of three periods of peak, regular and valley. The conditions for the user side to perform demand response are $C_{s_{i}}^{(1)} \leq C_{s_{i}}^{(0)}$, At the same time, peak valley electricity price to meet certain conditions $p_{\text {micro, } p} \leq \sigma p_{\text {micro, } v}$, here $1<\sigma \leq 3$.

(4) Constraints on the number of microgrid components

$$
\left\{\begin{array}{l}
N_{W} \leq N_{W}^{\max } \\
N_{B} \leq N_{B}^{\max } \\
N_{P V} \leq N_{P V}^{\max }
\end{array}\right.
$$

Among them, $N_{W}^{\max }, N_{B}^{\max }, N_{P V}^{\max }$ represents the upper limit of installed number of fan, energy storage and photovoltaic respectively

(5) Weather factor [16][17][18][19][20]

Under different weather conditions, the load power curve is the most stable under sunny days, and the load power curve also fluctuates slightly under cloudy days. Under cloudy and rainy days, the load power curve fluctuates violently and frequently, and the output power is more affected.

On this basis, the weighted coefficient of the photovoltaic power generation efficiency considering the weather factor is approximately calculated.

$$
\theta=\left(n_{1} * \alpha_{1}+n_{2} * \alpha_{2}+n_{3} * \alpha_{3}+n_{4} * \alpha_{4}\right) / 365
$$

$n_{1}, n_{2}, n_{3}, n_{4}$ are the number of days in a year when it is sunny, cloudy, cloudy and rainy. $\alpha_{1}, \alpha_{2}, \alpha_{3}, \alpha_{4}$ are the equivalent power generation efficiency coefficient when the unit value of sunny days is 1 . After weighted average, the annual photovoltaic power generation is multiplied by the average weighted coefficient $\theta$.

\section{RESULTS}

In 2018 , the electricity consumption of the whole society in Ganzhou was 18.647 billion kWh, an increase of 6\% compared with that of 2017. Industrial electricity consumption was 9.955 billion kilowatt-hours, up 10.1\%, or $7 \%$ more than in 2017 .

So the growth rate $r$ considers the capacity increment respectively according to the lower limit of $6 \%$ and the upper limit of $12 \%$, in addition, the capacity of the microgrid is larger than that of the transformer at peak times to meet the demand for power supply therefore, take $5 \mathrm{~T}$, solar and wind power with a typical day in all the year round as shown in figure 1,2 load to select a few public variable load as regional load, the sum of the simplified computing a year the four seasons in a day its value as a calculation basis, as shown in figure 3 . 


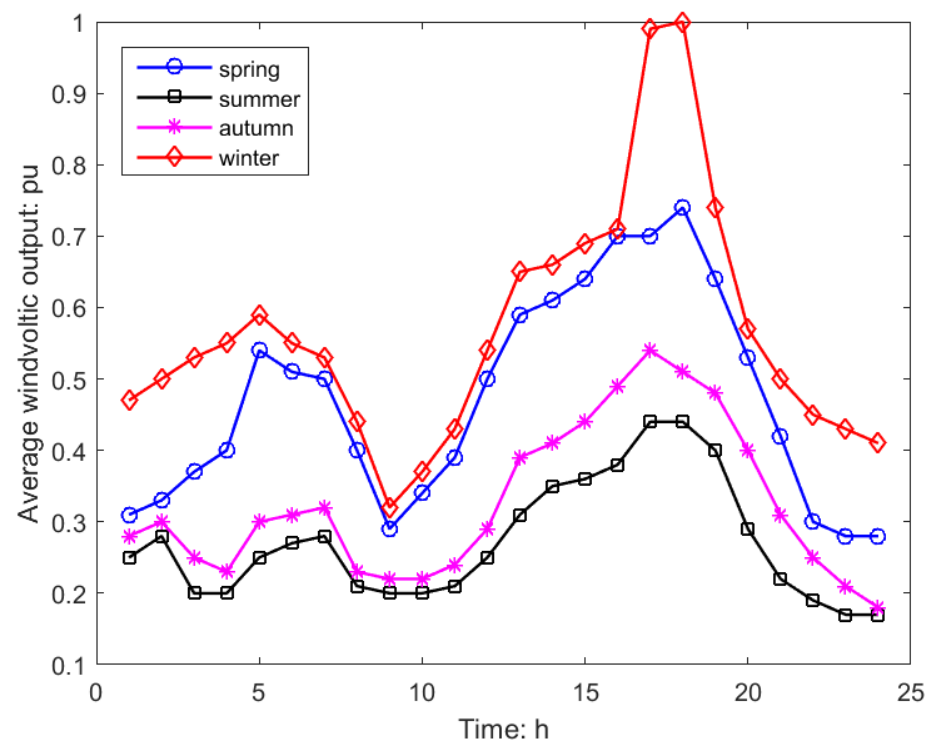

Figure1 Average output curve of fan in four seasons.

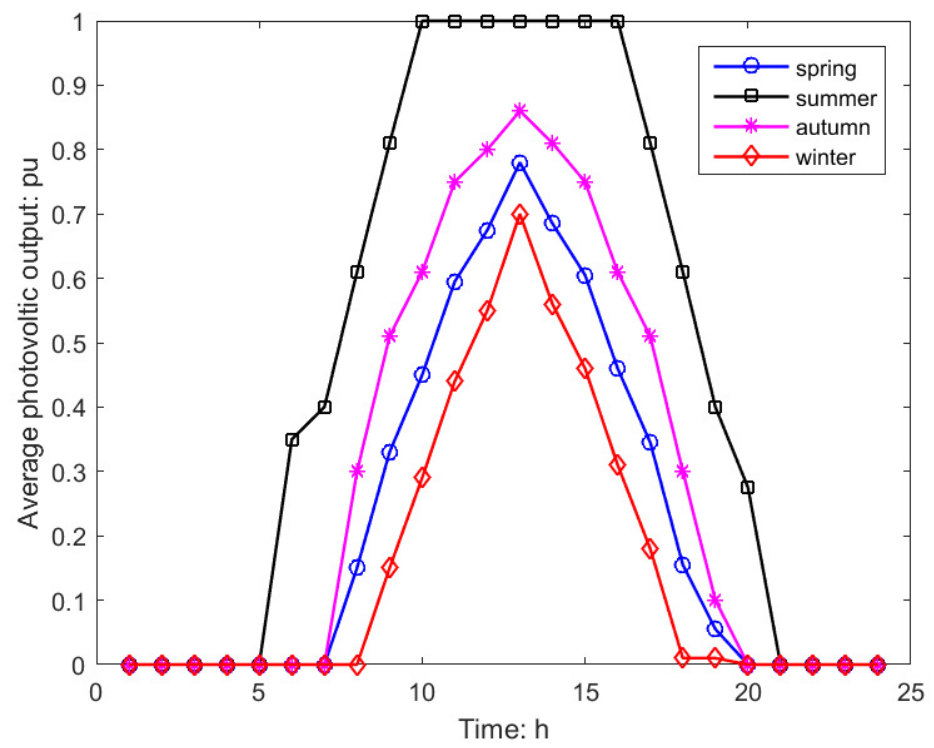

Figure2 Four seasons of photovoltaic output curve (On a sunny day). 


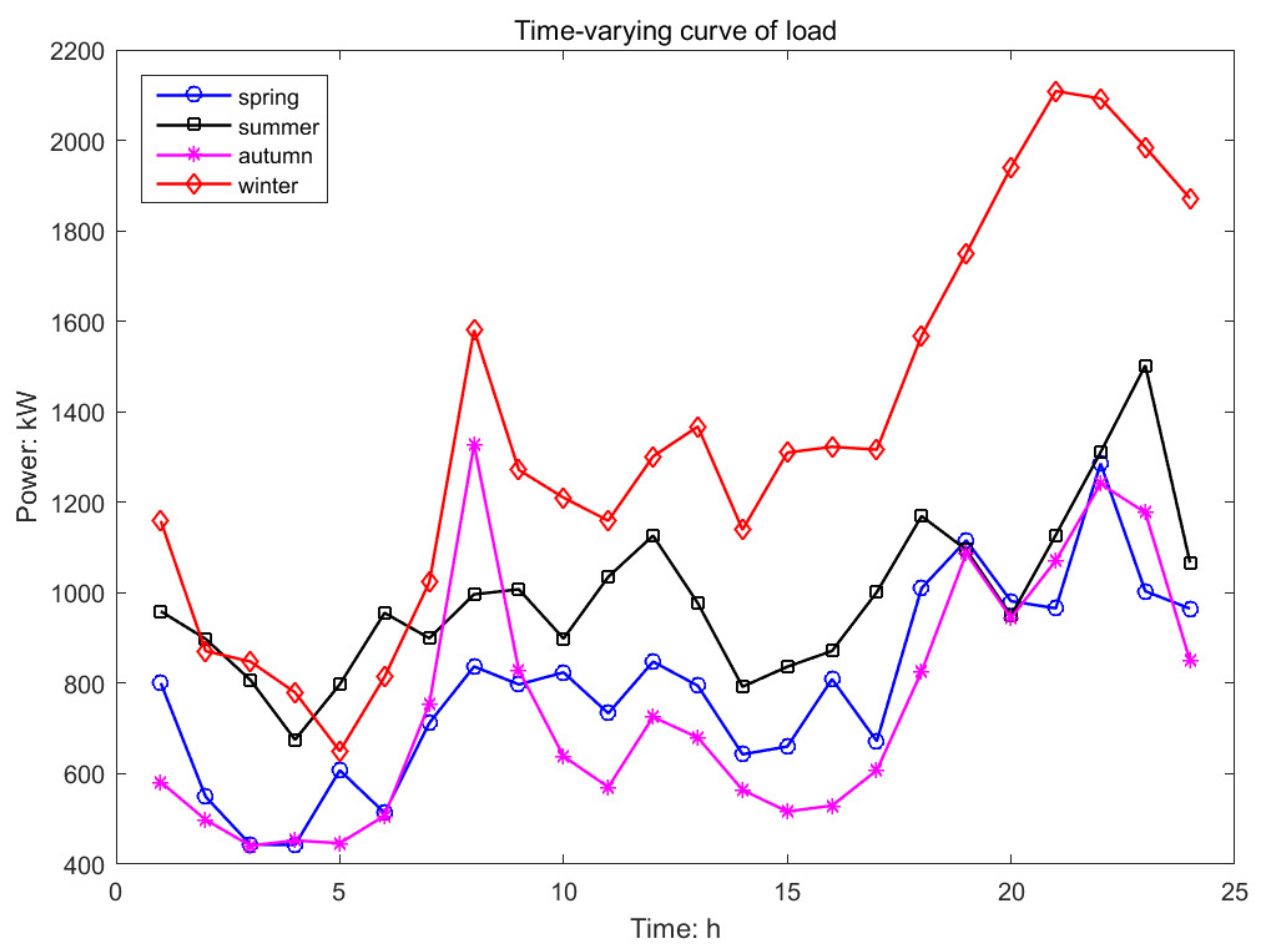

Figure3 Four seasons of average user load curve.

Located in the southern margin of the subtropical zone, Ganzhou is a subtropical monsoon climate zone, with prevailing winter and summer monsoon, concentrated precipitation in spring and summer, distinct four seasons, mild climate, abundant heat, abundant rainfall, short period of extreme heat and cold flow, long frost-free period and other climatic characteristics. From January 1, 2011 to October 1, 2020, Ganzhou has 1376 cloudy days, 1286 rainy days, 523 cloudy days, 279 sunny days, 14 snowy days, 10 days, to calculate the weighted coefficient on average.

Table 1 The weather conditions of Ganzhou

\begin{tabular}{|c|c|c|c|c|}
\hline Weather & Sunny day & Cloudy & Overcast sky & Rainy \\
\hline Days of weather & 279 & 1376 & 523 & 1286 \\
\hline Weather ratio & $8.05 \%$ & $39.72 \%$ & $15.10 \%$ & $37.12 \%$ \\
\hline Weather photovoltaic average power & 8.46 & 4.36 & 1.01 & 1.26 \\
\hline Weighted average power & \multicolumn{4}{|c|}{3.033571} \\
\hline Per-unit value & \multicolumn{4}{|c|}{$3.033571 / 8.46$} \\
\hline
\end{tabular}

Time-of-use electricity price is implemented in Ganzhou. It is 18:00-23:00 in summer (July and August), 16:00-21:00 in winter (1, December), 17:00-22:00 in other months, 20:00-22:00 in summer, 17:00-19:00 in winter, 0:00-8:00 in trough, and the rest of the period is flat. The maximum peak price is 0.91 yuan $/ \mathrm{kWh}$, the maximum peak price is $0.61 \mathrm{yuan} / \mathrm{kWh}$, the maximum flat price is
0.4143 yuan $/ \mathrm{kWh}$, and the maximum undervalued price is 0.245 yuan $/ \mathrm{kWh}$. In order to simplify the calculation, the peak and peak are taken as one value in the elastic matrix, and are calculated according to the actual situation in the electricity fee income. Other parameters are shown in the table. Because it is a nonlinear programming model, Lingo software is used to solve the problem

Table 2 Main parameters of microgrid regional planning

\begin{tabular}{|c|c|c|c|c|c|c|c|}
\hline $\begin{array}{c}\text { Transformer } \\
\text { rating }\end{array}$ & $\begin{array}{c}\text { Battery } \\
\text { life }\end{array}$ & $\begin{array}{c}\text { Fan } \\
\text { system } \\
\text { life }\end{array}$ & $\begin{array}{c}\text { Photovoltaic } \\
\text { life }\end{array}$ & $\begin{array}{c}\text { Battery energy } \\
\text { storage } \\
\text { Installation cost }\end{array}$ & $\begin{array}{c}\text { Battery storage } \\
\text { energy } \\
\text { replacement cost }\end{array}$ & $\begin{array}{c}\text { Discount } \\
\text { rate }\end{array}$ & $\begin{array}{c}\text { The main grid } \\
\text { unified electricity } \\
\text { price }\end{array}$ \\
\hline $2800 \mathrm{KW}$ & 10 years & 15 years & 20 years & 1000 yuan & 1000 yuan & 0.08 & 0.391 yuan \\
\hline
\end{tabular}

Table 3 Main parameters of wind-light-energy storage system

\begin{tabular}{|c|c|c|}
\hline Equipment & Parameter & Numerical value \\
\hline \multirow{2}{*}{ Photovoltaic array } & Installation charge/( Yuan/kW) & 3500 \\
\cline { 2 - 3 } & Replacement cost/( Yuan/kW) & 3000 \\
\hline
\end{tabular}




\begin{tabular}{|c|c|c|}
\hline & Life/years & 20 \\
\hline \multirow{3}{*}{ Wind driven generator } & Installation charge/(Yuan/unit) & 35000 \\
\cline { 2 - 3 } & Replacement cost/(Yuan/unit) & 30000 \\
\cline { 2 - 3 } & Life/years & 15 \\
\hline \multirow{3}{*}{ Storage battery } & Installation charge/(Yuan/piece) & 900 \\
\cline { 2 - 3 } & Replacement cost/(Yuan/piece) & 900 \\
\cline { 2 - 3 } & Life/year & 8 \\
\hline
\end{tabular}

The elastic matrix is

$$
M=\left[\begin{array}{ccc}
-0.13 & 0.07 & 0.10 \\
0.07 & -0.21 & 0.15 \\
0.10 & 0.15 & -0.21
\end{array}\right]
$$

Calculated results according to the example are shown in the following table

Table 4 Microgrid planning scheme under different parameters

\begin{tabular}{|c|c|c|c|c|c|c|c|c|c|}
\hline & $\begin{array}{l}\text { Load } \\
\text { growth } \\
\text { factor }\end{array}$ & $\begin{array}{c}\text { Elastic } \\
\text { demand }\end{array}$ & $\begin{array}{l}\text { Subsidy } \\
\text { (yuan) }\end{array}$ & $\begin{array}{c}\text { The } \\
\text { weather } \\
\text { factor }\end{array}$ & $\begin{array}{l}\text { Abandoned electric } \\
\text { punishment } \\
\text { (yuan })\end{array}$ & $\begin{array}{c}\text { The fan } \\
\text { number } \\
\text { (unit } \\
\text { ) }\end{array}$ & $\begin{array}{l}\text { Energy } \\
\text { storage } \\
\text { quantity } \\
\text { (group) }\end{array}$ & $\begin{array}{c}\text { Photovoltaic } \\
\text { number } \\
\text { (group) }\end{array}$ & $\begin{array}{c}\text { Total revenue } \\
\text { (yuan) }\end{array}$ \\
\hline $\begin{array}{c}\text { Case } 0 \\
1\end{array}$ & 0.06 & 0 & 0 & 1 & 0 & 250 & 0 & 590 & $\begin{array}{c}0.2736332 \mathrm{E}+ \\
08\end{array}$ \\
\hline $\begin{array}{c}\text { Case } 0 \\
2\end{array}$ & 0.12 & 0 & 0 & 1 & 0 & 250 & 0 & 334 & $\begin{array}{c}0.3258696 \mathrm{E}+ \\
08\end{array}$ \\
\hline $\begin{array}{c}\text { Case } 0 \\
3\end{array}$ & 0.06 & 0 & 0.4 & 1 & 0 & 250 & 2810 & 902 & $\begin{array}{c}0.6502903 \mathrm{E}+ \\
08\end{array}$ \\
\hline $\begin{array}{c}\text { Case } 0 \\
4\end{array}$ & 0.12 & 0 & 0.4 & 1 & 0 & 250 & 1404 & 1053 & $\begin{array}{c}0.7500264 \mathrm{E}+ \\
08\end{array}$ \\
\hline $\begin{array}{c}\text { Case } 0 \\
5 \\
\end{array}$ & 0.06 & 0 & 0 & 0.3586 & 0 & 250 & 0 & 0 & $\begin{array}{c}0.2761141 \mathrm{E}+ \\
08 \\
\end{array}$ \\
\hline $\begin{array}{c}\text { Case } 0 \\
6\end{array}$ & 0.12 & 0 & 0 & 0.3586 & 0 & 250 & 0 & 0 & $\begin{array}{c}0.3188198 \mathrm{E}+ \\
08\end{array}$ \\
\hline $\begin{array}{c}\text { Case } 0 \\
7\end{array}$ & 0.06 & 0 & 0.4 & 0.3586 & 0 & 416 & 1069 & 0 & $\begin{array}{c}0.6852532 \mathrm{E}+ \\
08\end{array}$ \\
\hline $\begin{array}{c}\text { Case } 0 \\
8\end{array}$ & 0.12 & 0 & 0.4 & 0.3586 & 0 & 250 & 2494 & 0 & $\begin{array}{c}0.6804064 \mathrm{E}+ \\
08\end{array}$ \\
\hline
\end{tabular}

Can be seen from table 4 does not consider that electricity punishment, considered in line with the annual growth rate for 6 and 12\% respectively, the distributed power supply with subsidies and without subsidies, as well as consider the weather factor 1 respectively and according to the actual weather data for 0.3586 Ganzhou region a total of eight kinds of circumstances, can be seen from the table above, there are subsidies because of the distributed power generation cost reduction, by a large increase in energy storage components, reduce the power grid electricity purchasing, mainly composed of distributed power generation to improve efficiency in power generation company, and without subsidies, mainly considering the system transmission capacity as far as possible from the grid power purchase, a small amount of the distributed power supplement, after considering the weather factors, Due to wet weather Ganzhou region is more, the equivalent coefficient is small, photovoltaic actual costs rise, pv planning is zero, photovoltaic location try to choose in lighting time is long, can according to different specific areas of Ganzhou district concrete data, makes the weather factor as far as possible close to 1, otherwise the photovoltaic (pv) and more rain is not suitable for the southern region, can consider appropriately biogas to generate electricity.

Table 5 Effect of implementing TOU price on microgrid planning scheme

\begin{tabular}{|c|c|c|c|c|c|c|c|c|c|}
\hline & $\begin{array}{c}\text { Load } \\
\text { growth } \\
\text { factor }\end{array}$ & $\begin{array}{c}\text { Elastic } \\
\text { demand }\end{array}$ & $\begin{array}{c}\text { Subsidy } \\
\text { (yuan) }\end{array}$ & $\begin{array}{c}\text { The } \\
\text { weather } \\
\text { factor }\end{array}$ & $\begin{array}{c}\text { Abandoned } \\
\text { electric } \\
\text { punishment } \\
\text { (yuan) }\end{array}$ & $\begin{array}{c}\text { The fan } \\
\text { number } \\
\text { (unit) }\end{array}$ & $\begin{array}{c}\text { Energy } \\
\text { storage } \\
\text { quantity } \\
\text { (group) }\end{array}$ & $\begin{array}{c}\text { Photovoltaic } \\
\text { number } \\
\text { (group) }\end{array}$ & $\begin{array}{c}\text { Total revenue } \\
\text { (yuan) }\end{array}$ \\
\hline $\begin{array}{c}\text { Case03-Inelastic } \\
\text { demand }\end{array}$ & 0.06 & 0 & 0.4 & 1 & 0 & 250 & 2810 & 902 & $0.6502903 \mathrm{E}+08$ \\
\hline $\begin{array}{c}\text { Case03-elastic } \\
\text { demand }\end{array}$ & 0.06 & matrix $>0$ & 0.4 & 1 & 0 & 250 & 3750 & 671 & $0.6085906 \mathrm{E}+08$ \\
\hline
\end{tabular}

It can be seen from the above table that, after considering the elastic matrix, the residential electricity consumption decreases and the newly added distributed power supply decreases. This indicates that after the TOU price factor is added, the investment of distributed power supply and energy storage unit decreases due to the decrease of residential conforming electricity consumption, thus reducing the total investment cost. 
After considering the time-sharing electricity price, although the total operating revenue, reduce the total cost of investment, but due to a significant decrease in the total revenue, thereby increasing the supply systems promoted the economy of the whole system, since this case by using data for change, load power consumption are greatly influenced by price factor, if the change, big orders affects industrial load and electricity price is not as time-sharing electricity prices significantly lower load demand, also

Table 6 Effects of power abandonment penalty on microgrid planning scheme and total revenue

\begin{tabular}{|c|c|c|c|c|c|c|c|c|c|c|}
\hline & $\begin{array}{l}\text { Load } \\
\text { growth } \\
\text { factor }\end{array}$ & $\begin{array}{c}\text { Elasti } \\
\text { c } \\
\text { dema } \\
\text { nd }\end{array}$ & $\begin{array}{l}\text { Subsidy } \\
\text { (yuan } \\
\text { ) }\end{array}$ & $\begin{array}{l}\text { The } \\
\text { weathe } \\
\text { r factor }\end{array}$ & $\begin{array}{c}\text { Abandoned } \\
\text { electric } \\
\text { punishmen } \\
\text { t } \\
\text { (yuan) }\end{array}$ & $\begin{array}{l}\text { The fan } \\
\text { number } \\
\text { (unit } \\
\text { ) }\end{array}$ & $\begin{array}{c}\text { Energy } \\
\text { storage } \\
\text { quantity } \\
\text { (group } \\
\text { ) }\end{array}$ & $\begin{array}{l}\text { Photovoltai } \\
\text { c number } \\
\text { (group) }\end{array}$ & $\begin{array}{c}\text { Total } \\
\text { revenue } \\
\text { (yuan } \\
\text { ) }\end{array}$ & \\
\hline \multirow{2}{*}{$\begin{array}{c}\text { Case03-NO } \\
\text { Abandoned electric } \\
\text { punishment }\end{array}$} & 0.06 & 0 & 0.4 & 1 & 0 & 250 & 2810 & 905 & $\begin{array}{c}0.650290 \\
3 \mathrm{E}+08\end{array}$ & Calculate 1 \\
\hline & 0.06 & 0 & 0.4 & 1 & 0 & 250 & 748 & 568 & $\begin{array}{c}0.640750 \\
8 \mathrm{E}+08\end{array}$ & Calculate 2 \\
\hline $\begin{array}{c}\text { Case03-Abandoned } \\
\text { electric punishment } \\
-1 \\
\end{array}$ & 0.06 & 0 & 0.4 & 1 & 0.5 & 214 & 1995 & 435 & $\begin{array}{c}0.569126 \\
0 \mathrm{E}+08\end{array}$ & \\
\hline $\begin{array}{l}\text { Case03-Abandoned } \\
\text { electric punishment } \\
-2\end{array}$ & 0.06 & 0 & 0.4 & 1 & 1.0 & 177 & 2522 & 322 & $\begin{array}{c}0.569126 \\
E+08\end{array}$ & \\
\hline $\begin{array}{l}\text { Case03-Abandoned } \\
\text { electric punishment } \\
-3\end{array}$ & 0.06 & 0 & 0.4 & 1 & 1.5 & 172 & 2450 & 249 & $\begin{array}{c}0.528063 \\
0 \mathrm{E}+08\end{array}$ & \\
\hline $\begin{array}{c}\text { Case03-Abandoned } \\
\text { electric punishment } \\
-4\end{array}$ & 0.06 & 0 & 0.4 & 1 & 2.0 & 186 & 3501 & 407 & $\begin{array}{c}0.511722 \\
8 \mathrm{E}+08\end{array}$ & \\
\hline
\end{tabular}

Since power generation, transmission, distribution and electricity consumption are completed simultaneously in the power system, in order to ensure the reliability of power supply, there is usually no power failure for users. However, due to the great randomness of user load, it is inevitable that the power failure will occur. Now generating capacity is greater than the electricity consumption, cause the happening of the distributed power away, and if in order to avoid electricity, reduce the distribution of power supply capacity, at the time of peak demand is difficult to meet user demand, with the abovementioned can be seen, according to the scheme of the won't reduce the distributed power and energy storage components of investment, the current national emphasis on the importance of environmental protection, only to save energy, reduce energy consumption, to fundamentally prevent environmental pollution and destruction, In the specific planning, not only the benefits of power supply enterprises should be considered, but also the relevant social costs should be considered.

Table 7 Several typical schemes and microgrid planning investment income

\begin{tabular}{|c|c|c|c|c|c|c|c|c|c|}
\hline & $\begin{array}{l}\text { Load } \\
\text { growth } \\
\text { factor }\end{array}$ & $\begin{array}{l}\text { Elastic } \\
\text { demand }\end{array}$ & $\begin{array}{l}\text { Subsidy } \\
\text { (yuan) }\end{array}$ & $\begin{array}{c}\text { The } \\
\text { weather } \\
\text { factor }\end{array}$ & $\begin{array}{c}\text { Abandoned } \\
\text { electric } \\
\text { punishment } \\
\text { (yuan) }\end{array}$ & $\begin{array}{c}\text { The fan } \\
\text { number } \\
\text { (unit } \\
\text { ) }\end{array}$ & $\begin{array}{l}\text { Energy } \\
\text { storage } \\
\text { quantity } \\
\text { (group) }\end{array}$ & $\begin{array}{c}\text { Photovoltai } \\
\text { c number } \\
\text { (group) }\end{array}$ & $\begin{array}{c}\text { Total revenue } \\
\text { (yuan) }\end{array}$ \\
\hline Scheme 1 & 0.06 & 0 & 0.4 & 1 & 0 & 250 & 748 & 568 & $\begin{array}{c}0.6407508 \mathrm{E}+0 \\
8\end{array}$ \\
\hline Scheme 2 & 0.06 & 0 & 0.4 & 1 & 1.0 & 177 & 2522 & 322 & $\begin{array}{c}0.5280630 \mathrm{E}+0 \\
8\end{array}$ \\
\hline Scheme 3 & 0.12 & 0 & 0.4 & 1 & 0 & 250 & 1404 & 1053 & $\begin{array}{c}0.7500264 \mathrm{E}+0 \\
8\end{array}$ \\
\hline
\end{tabular}

Table 8 Several typical schemes and microgrid planning specific investment income data

\begin{tabular}{|c|c|c|c|c|c|c|c|c|c|c|c|}
\hline Scheme & $\begin{array}{l}\text { Fan } \\
\text { (yuan } \\
\text { ) }\end{array}$ & $\begin{array}{c}\text { Photovoltaic } \\
\text { (yuan) }\end{array}$ & $\begin{array}{c}\text { Energy } \\
\text { storage } \\
\text { (yuan } \\
\text { ) }\end{array}$ & $\begin{array}{c}\text { Total } \\
\text { investment } \\
\text { (yuan) }\end{array}$ & $\begin{array}{c}\text { Sell } \\
\text { electricity } \\
\text { (yuan) }\end{array}$ & $\begin{array}{c}\text { DG } \\
\text { subsidy } \\
\text { (yuan } \\
\text { ) }\end{array}$ & $\begin{array}{l}\text { Electricity } \\
\text { purchase } \\
\text { (yuan) }\end{array}$ & $\begin{array}{l}\text { Abandoned } \\
\text { electric } \\
\text { (yuan) }\end{array}$ & $\begin{array}{c}\text { Operation } \\
\text { and } \\
\text { maintenance } \\
\text { (yuan) }\end{array}$ & $\begin{array}{c}\text { Total } \\
\text { operation } \\
\text { (yuan) }\end{array}$ & $\begin{array}{c}\text { Total } \\
\text { revenue } \\
\text { (yuan } \\
\text { ) }\end{array}$ \\
\hline $\begin{array}{c}\text { Scheme } \\
1\end{array}$ & 9862799 & 1988000 & 1254951 & $\begin{array}{c}0.1310575 \\
E+08\end{array}$ & $\begin{array}{c}0.4706486 \\
E+08\end{array}$ & $\begin{array}{l}0.36946 \\
75 \mathrm{E}+08\end{array}$ & 6270593 & 0 & 560184.2 & $\begin{array}{c}0.7718083 \\
E+08\end{array}$ & $\begin{array}{l}0.64075 \\
08 \mathrm{E}+08\end{array}$ \\
\hline $\begin{array}{c}\text { Scheme } \\
2\end{array}$ & 6982862 & 1127000 & 4231265 & $\begin{array}{c}0.1234113 \\
E+08\end{array}$ & $\begin{array}{c}0.4706486 \\
E+08\end{array}$ & $\begin{array}{l}0.31742 \\
51 \mathrm{E}+08\end{array}$ & $\begin{array}{c}0.1135773 \\
E+08\end{array}$ & 1831351. & 470868.5 & $\begin{array}{c}0.6514742 \\
E+08\end{array}$ & $\begin{array}{l}0.52806 \\
30 \mathrm{E}+08\end{array}$ \\
\hline $\begin{array}{c}\text { Scheme } \\
3\end{array}$ & 9862799 & 3685500 & 2355549 & $\begin{array}{c}0.1590385 \\
E+08\end{array}$ & $\begin{array}{c}0.5792599 \\
E+08\end{array}$ & $\begin{array}{l}0.43398 \\
45 \mathrm{E}+08\end{array}$ & 9745449 & 0.000000 & 672498.9 & $\begin{array}{c}0.9090649 \\
E+08\end{array}$ & $\begin{array}{l}0.75002 \\
64 \mathrm{E}+08\end{array}$ \\
\hline
\end{tabular}


By the table 7 table 8 can see through, under different growth rate of electricity transformer capacity limit and the photovoltaic (pv) power supply under different weather efficiency under different conditions, based on time division of micro network life period yields highest net present value as a target for solving the three typical schemes of relevant data, so as to provide theory support for the Ganzhou district micro network planning.

\section{CONCLUSION}

According to the specific load data of the region, the specific wind force, photovoltaic output, the relationship of photovoltaic affected by the weather, and the penalty for abandoning electricity, this paper provides a variety of planning schemes for reference [21][22][23].

Due to the changes of various factors, in actual work, in order to better serve the power consumption enterprises, we provide a variety of planning schemes to supply and power consumption enterprises, which can be seen from the above analysis:

1. Without increasing the transmission capacity of the system, the excess part must be provided by the distributed power supply as the user's power load surges. Although this seems to reduce the revenue, it reduces the cost of power supply by reducing the investment in system upgrading, and improves the economy of system power supply on the whole.

2. After considering the weather factor, it can be found that the south is not suitable for a large number of photovoltaic power supply due to the rainy weather. However, in practical application, we can select sunny places for installation according to the specific small range of weather, or consider other distributed power sources such as biogas, gas and fuel.

3. Enterprise production is greatly affected by the policy. If there is no subsidy for distributed generation, or the penalty for abandoning power is high, the cost of enterprise power generation will rise, and the power purchase from the system will be increased, while the increase of system transmission capacity means the cost of infrastructure will be greatly increased.

4. Since the user load is affected by a variety of factors and the power production cycle is long, the original scheme can be revised within the planning period according to the change of relevant factors, so as to improve the enterprise income.

5. TOU electricity price is conducive to reducing the user's electricity demand, flattening the peak and suppressing the valley, reducing carbon emissions and improving the overall social benefits.

The current plan still has the following shortcomings.

1. Big data management, because load changes are affected by a variety of factors, such as weather, emergency (such as 20 years of new crown epidemic caused by economic development and changes in residential electricity consumption), load prediction has great uncertainty, especially the specific days of shortterm planning is not only difficult to predict, a large number of data also makes it difficult to calculate.

2. Unpredictable policy changes, such as subsidies for distributed generation and penalties for abandoning power, have reduced the accuracy of planning.

3. Scientific and technological developments, such as photovoltaic, wind and energy storage, have changed unit costs, affecting the planning of distributed generation.

Through the improvement of related mathematical methods and the improvement of science and technology, the overall cost of electricity must be greatly reduced and the reliability of power supply system is constantly improved.

\section{REFERENCES}

1. Jiating Long. Research on economic operation optimization of microgrid with distributed power supply [D]. Nanchang: Nanchang University, 2020.

2. Shixuan Wang, Wu Zhu. A review of planning research on cogeneration microgrid [J]. Electrical Measurement \& Instrumentation, 2020.

3. Bin Zhang, Li Yu et al. Layout planning method of automatic terminal of rural active distribution network [J]. Journal of Agricultural University of Hebei, 2020, 43(4): 134-140

4. Zhigao Li. Application of ant colony algorithm in planning of $500 \mathrm{kV}$ transmission network in Jiangxi province in 2030 [D]. Nanchang: Nanchang University, 2019.

5. Bo Zhou, Peipei Xu. Application of regional distributed energy system based on typical business park [J]. Shanghai Energy Conservation, 2020, 11: 565-569.

6. Shan Cheng, Tianli Huang et al. Optimal operation of cogeneration microgrid based on multi-energy complementarity $[\mathrm{J}]$. Power System Protection and Control,2020,48(11): 161-168.

7. Lan Zhu, Shuhong Yang et al. Comprehensive evaluation of microgrid planning based on improved ANP [J] Journal of Solar Energy, 2020, 41(3): 141148.

8. Hao Zhen, Bofeng $\mathrm{Xu}$ et al. Research on allocation strategy based on photovoltaic hybrid energy storage [J]. Water Power, 2020.

9. Fuping Zhang, Zhihong Li et al. Game optimization of energy storage capacity of microgrid considering uncertainty of distributed power supply [J]. Renewable Energy Sources, 2019,37(7): 1043-1048.

10. bin Che, Yanzhang Liu et al. Risk assessment method of distribution network taking into account the randomness of distributed photovoltaic output [J]. Renewable Energy Sources, 2019, 37(11): 1685-1690.

11. Xiangyu Zhu, Renli Cheng et al. Optimizing the operation of microgrid with photovoltaic gridconnection [J]. New Energy Systems and Equipment, 2020, 4: 58-63.

12. Yong $\mathrm{Wu}, \mathrm{Lin} \mathrm{Lu}$ et al. Optimal allocation of microgrid considering time division of TOU price [J]. Electrical measurement and instrumentation, 2020, 57(11): 55-62. 
13. Qiang Xu, Jian $\mathrm{Wu}$ et al. A two-stage stochastic programming method for multi-energy microgrid systems considering new energy sources and load uncertainty $[\mathrm{J}]$. Electric Power Construction, 2020, 41(4): 101-107.

14. Yu Li, Zengqiang Zhang et al. Integrated energy system planning method combined with microgrid operation mode $[\mathrm{J}]$. Optimized planning for the comprehensive energy system, 2020, 48(16): 40-46.

15. Shunfu Lin, Dongdong Li et al. Two-layer and multiscene collaborative optimal configuration of multimicro grid system in hot and cold power region considering energy interaction $[\mathrm{J}]$. Proceedings of the CSEE, 2020, 40(5): 1410-1420.

16. Fashun Wang. Active distribution network planning and elasticity evaluation considering multiple stakeholders. [D]. Shanghai: Shanghai University of Electric Power, 2020.

17. Hui Sun, Jianwei Len. Short-term photovoltaic power generation prediction based on improved Semi Boost weather clustering CC-PSO-DBN [J]. Computer applications and software, 2020,37(8): 104-109.

18. Fen Li, Yong Yang et al. Energy evaluation and optimization of tracking photovoltaic power generation system based on weather type recognition
[J]. Journal of Solar Energy, 2020, 41(11): 113-119.

19. Shuang Han, Yanping $\mathrm{Xu}$ et al. A method for complementary analysis of wind-landscape output considering synoptic types [J]. Automation of Electric Power Systems, 2020.

20. Yuan Ma, Xuemin Zhang et al. Ultra-short-term photovoltaic power projections based on a modified clear-sky model [J]. Automation of Electric Power Systems, 2020.

21. Hongzhong Li, Menglin Lu et al. Joint planning of microgrid considering generalized energy storage $[\mathrm{J}]$. Electric Power Automation Equipment, 2020, 40(7): 150-155.

22. Shaoyun Ge, Yuchen Cao et al. Energy supply capacity assessment of integrated energy microgrid considering reliability constraints $[\mathrm{J}]$. Automation of Electric Power Systems, 2020, 44(7): 31-37.

23. Chao Jiang. Multi-energy complementary microgrid interval planning considering source-charge uncertainty [D]. Jilin: Northeast Electric Power University, 2020.

24. Lan Zhu, Peiyuan Liu et al. Robust Optimal Operation of Micro-energy Considering Direct Load Control Uncertainties [J]. Power System Technology, 2020, 44(4): 1401-1409. 